\title{
Correction to: Evolution and diversity of the angiosperm anther: trends in function and development
}

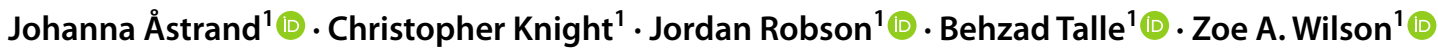

Published online: 13 September 2021

(c) The Author(s) 2021

\section{Correction to: Plant Reproduction https://doi.org/10.1007/s00497-021-00416-1}

The original article has been corrected.

Unfortunately, the original publication of the article has an error in the labelling on Fig. 3. The correct figure is given in this correction.

Fig. 3 Anther wall formation types (adapted from Davis 1966). In all formation types, the epidermis (dark blue) surrounds the primary parietal cells that differentiate to form secondary parietal cells. The SP cells then differentiate into the endothecium (light blue), middle layer (dark green) and tapetum (light green), according to the formation type associated with each species. Ep: epidermis, En: endothecium, M: middle layer, PP: primary sporogenous cells, SP: secondary sporogenous cells, T: tapetum

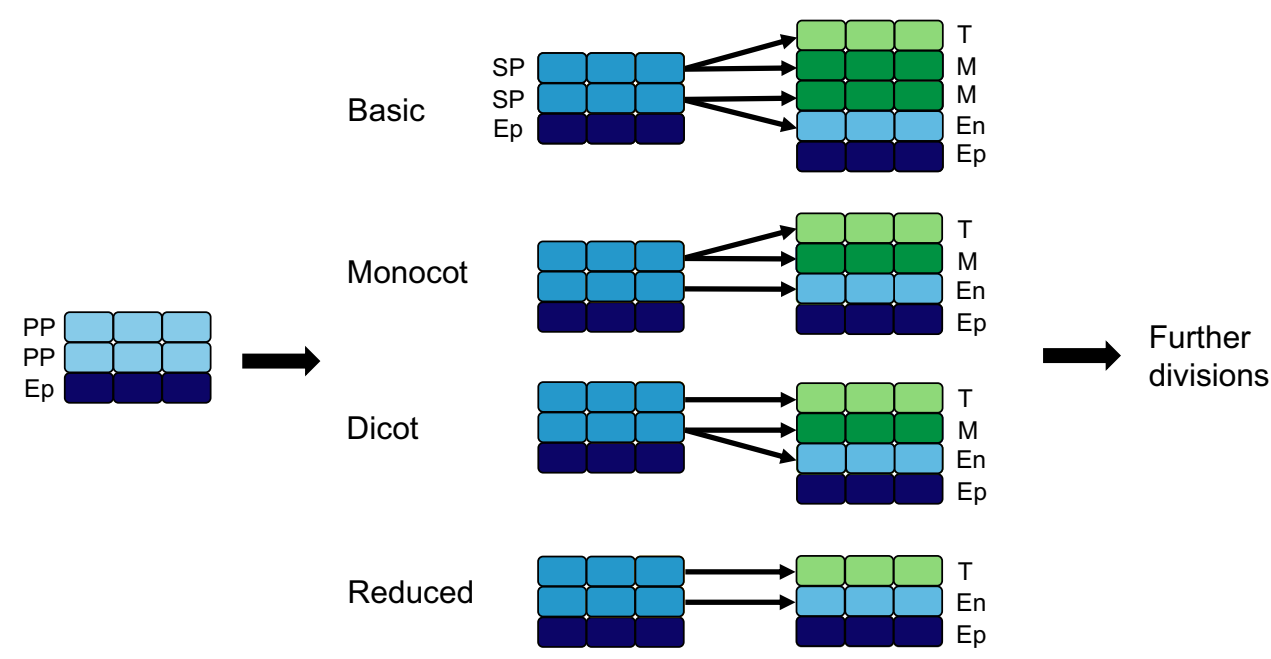

Open Access This article is licensed under a Creative Commons Attribution 4.0 International License, which permits use, sharing, adaptation, distribution and reproduction in any medium or format, as long as you give appropriate credit to the original author(s) and the source, provide a link to the Creative Commons licence, and indicate if changes were made. The images or other third party material in this article are included in the article's Creative Commons licence, unless indicated otherwise in a credit line to the material. If material is not included in the article's Creative Commons licence and your intended use is not permitted by statutory regulation or exceeds the permitted use, you will need to obtain permission directly from the copyright holder. To view a copy of this licence, visit http://creativecommons.org/licenses/by/4.0/.

Publisher's Note Springer Nature remains neutral with regard to jurisdictional claims in published maps and institutional affiliations. 